\title{
Pelatihan Pengenalan Rambu-Rambu Lalu Lintas dan Prioritas Pengguna Jalan Menggunakan Media Interaktif
}

\author{
Eka Larasati Amalia*, Vivin Ayu Lestari ${ }^{2}$, Mustika Mentari ${ }^{3}$, Farida Ulfa ${ }^{4}$, Vivi Nur Wijayaningrum ${ }^{5}$, \\ Chintya Puspa Dewi ${ }^{6}$, Dimas Shella Charlinawati ${ }^{7}$, Ermi Pristiyaningrum ${ }^{8}$ \\ 1,2,3,4,5,6,7,8 Jurusan Teknologi Informasi, Politeknik Negeri Malang \\ e-mail: *11eka.larasati@polinema.ac.id, ${ }^{2}$ vivinlestari91@gmail.com, ${ }^{3}$ must.mentari@polinema.ac.id, \\ 4faridaulfa@polinema.ac.id, ${ }^{5}$ vivinurw@polinema.ac.id, ${ }^{6}$ chintyadewi437@gmail.com, \\ 7dimasshella04@gmail.com, ${ }^{8}$ ermi.pristiya@gmail.com
}

\begin{abstract}
Abstrak
Tingginya minat anak-anak terhadap teknologi menyebabkan pentingnya dilakukan pengarahan agar dapat memanfaatkan teknologi untuk kegiatan pembelajaran secara positif. Anak-anak sebagai generasi penerus bangsa harus dapat dididik secara benar untuk menjadi generasi yang berkualitas melalui berbagai kegiatan seperti stimulasi, pengasuhan, pendampingan, dan pelatihan yang bertujuan untuk mengembangkan potensi dan pengetahuan agar dapat berkembang secara optimal. Kegiatan pengabdian pada masyarakat dianggap perlu dilakukan untuk memperkenalkan penggunaan teknologi yang bermanfaat kepada anak-anak di Taman Baca Galeri Kreatif. Kegiatan ini dikemas dalam bentuk pelatihan melalui sebuah aplikasi permainan tentang ramburambu lalu lintas dan prioritas pengguna jalan. Berdasarkan hasil uji coba permainan rambu-rambu lalu lintas dan prioritas pengguna jalan untuk anak-anak di Taman Baca Galeri Kreatif, diketahui minat dan antusias mereka dalam proses pembelajaran sangat tinggi. Hal ini dibuktikan dengan tingginya partisipasi para peserta didik dalam menjawab soal yang berkaitan dengan rambu-rambu lalu lintas secara tepat.
\end{abstract}

Kata kunci-anak-anak, media, pelatihan, permainan, teknologi

\section{PENDAHULUAN}

Sebagai generasi penerus bangsa, anak-anak perlu difasilitasi dengan pendidikan yang baik agar berhasil menjadi generasi yang berkualitas. Salah satu upaya untuk mendidik anak-anak adalah dengan menanamkan karakter gemar membaca di dalamnya diri mereka. Melalui kegemaran inilah, anak-anak dapat membiasakan diri sejak dini untuk berlatih memperoleh pengetahuan dari membaca buku karena pada dasarnya buku merupakan jendela informasi yang sangat penting [1][2].

Namun, permasalahan yang sering terjadi adalah sulitnya menumbuhkan kegemaran membaca pada anak-anak [3]. Hal ini dikarenakan mereka cenderung lebih tertarik untuk bermain melalui smartphone yang cenderung hanya berfungsi sebagai hiburan semata [4]. Sebenarnya, apabila difungsikan dengan baik, smartphone dapat digunakan sebagai media penunjang bagi anak-anak untuk belajar [5].

Untuk mendukung program peningkatan kualitas generasi penerus bangsa, Taman Galeri Baca Kreatif, yang berlokasi di Desa Wonokerto, Kecamatan Bantur, Kabupaten Malang, memberikan fasilitas bagi anak-anak untuk dapat belajar setiap hari dan mengikuti mini class selayaknya kursus mengenai pelajaran di sekolah dasar, seperti matematika, bahasa Indonesia, dan pelajaran lainnya. Tentor yang memberikan materi merupakan peserta didik lainnya yang berada di Taman Baca Kreatif dengan jenjang pendidikan lebih tinggi.

Di Taman Baca Galeri Kreatif ini, para peserta didik tidak hanya belajar mengenai mata pelajaran sekolah saja, melainkan juga belajar mengenai pengetahuan lainnya melalui koleksi buku dan pengenalan pemanfaatan teknologi melalui narasumber yang berasal dari luar Taman Baca Galeri Kreatif. Hal ini bertujuan untuk mengarahkan para peserta didik agar dapat memanfaatkan teknologi, misalnya smartphone, untuk digunakan sebagai media pembelajaran alternatif selain buku.

Berdasarkan pemaparan permasalahan umum yang terjadi pada anak-anak yang berkaitan dengan smartphone, serta kondisi yang terdapat pada Taman Baca Galeri Kreatif, maka kegiatan pengabdian pada masyarakat dilaksanakan dengan target peserta 100 anak, yang merupakan anak-anak didik di Taman Baca Galeri Kreatif dengan usia sekolah mulai dari Taman Kanak-kanak sampai tingkat Sekolah Dasar. 
Tujuan utama dari kegiatan pengabdian pada masyakarat ini adalah untuk membiasakan para peserta didik menggunakan teknologi sebagai media pembelajaran yang positif dan bermanfaat. Kegiatan yang dilakukan berupa pelatihan mengenai pengenalan rambu-rambu lalu lintas dan prioritas pengguna jalan yang dibentuk dalam sebuah aplikasi permainan. Pelatihan ini dianggap perlu bagi para peserta didik dikarenakan mereka rata-rata bertempat tinggal di wilayah pedesaan dan cenderung belum menjumpai berbagai jenis rambu-rambu lalu lintas dan prioritas pengguna jalan. Materi pelatihan disampaikan dalam bentuk permainan yang bersifat audio visual karena anak-anak cenderung merasa tertarik terhadap media pembelajaran yang bersifat audio visual dan interaktif [6]. Media audio visual dianggap dapat mempengaruhi kemampuan anakanak dalam mendengar dan memperhatikan materi yang disampaikan [7]. Dengan demikian, adanya kegiatan pelatihan yang dilaksanakan di Taman Baca Galeri Kreatif sebagai bentuk pengabdian kepada masyarakat diharapkan dapat memberikan pengetahuan dan menumbuhkan kesadaran sejak dini bagi para peserta didik mengenai rambu-rambu lalu lintas dan prioritas pengguna jalan dalam bentuk media interaktif.

Media pembelajaran merupakan segala sesuatu yang dapat digunakan untuk menyalurkan pesan (bahan pembelajaran), sehingga dapat merangsang perhatian, minat, pikiran, dan perasaan siswa dalam kegiatan belajar untuk mencapai tujuan belajar [8]. Media pembelajaran yang digunakan dalam proses belajar mengajar dapat membangkitkan minat, motivasi dan rangsangan kegiatan belajar, serta memberikan pengaruh psikologis terhadap siswa.

Beberapa manfaat penggunaan media pembelajaran dalam proses belajar mengajar antara lain [9]:

a. Proses pembelajaran menjadi lebih jelas dan menarik karena media dapat menampilkan informasi melalui gambar, suara, gerakan, dan warna, baik secara alami maupun manipulasi.

b. Proses pembelajaran menjadi lebih interaktif karena dengan adanya media maka akan terjadi komunikasi dua arah secara aktif.

c. Dengan adanya media pembelajaran, tujuan belajar akan lebih mudah tercapai secara maksimal dengan waktu dan tenaga seminimal mungkin sehingga dapat melakukan efisiensi waktu dan tenaga.

d. Media pembelajaran dapat membantu siswa menyerap materi belajar lebih mendalam dan utuh. Apabila siswa hanya mendengar informasi verbal dari guru saja, maka siswa menjadi kurang memahami pelajaran. Namun, jika proses pembelajaran diperkaya dengan kegiatan melihat, menyentuh, merasakan, dan mengalami sendiri melalui media, maka pemahaman siswa akan menjadi lebih baik.

e. Dengan adanya media pembelajaran, maka proses pembelajaran memungkinkan untuk dilakukan dimanapun dan kapanpun.

f. Media pembelajaran dapat menumbuhkan sikap positif siswa terhadap proses belajar. Proses pembelajaran menjadi lebih menarik sehingga mendorong siswa untuk mencintai ilmu pengetahuan dan rajin mencari sumber ilmu pengetahuan secara mandiri.

Lalu lintas merupakan cermin budaya bangsa, artinya perilaku berlalu lintas merupakan cermin dari apa yang diyakini, nilai-nilai dan pengetahuan yang dimiliki oleh suatu masyarakat bahkan suatu bangsa. Amanat dari PBB dibidang Road Safety salah satunya adalah dengan membangun RUNK (Rencana Umum Nasional Keselamatan) yang terdiri dari 5 pilar sebagai berikut [10]:

\section{Management Road Safety \\ 2. Safer Road \\ 3. Safer Vehicle \\ 4. Safer People \\ 5. Post Crash}

Keselamatan berlalu lintas menjadi salah satu priortas yang harus diperhatikan dan diutamakan oleh seluruh pihak. Untuk mencegah resiko terjadinya kecelakaan lalu lintas, pengguna jalan perlu memperhatikan keamanan, kenyamanan, dan kepatuhan terhadap peraturan lalu lintas. Oleh karena itu, aturan-aturan serta perangkat pendukung dalam kegiatan berlalu lintas disusun dalam bentuk ramburambu lalu lintas.

Menurut Undang-Undang No. 22 tahun 2009 tentang lalu lintas dan angkutan jalan, rambu lalu lintas adalah bagian perlengkapan jalan yang berupa lambang, huruf, angka, kalimat, dan/atau perpaduan yang berfungsi sebagai peringatan, larangan, perintah, atau petunjuk bagi pengguna jalan. Rambu lalu lintas di Indonesia antara lain Rambu Peringatan, Rambu Petunjuk, Rambu Larangan, Rambu Perintah serta Pengatur Lalu lintas yaitu aba-aba polisi [11].

Menggunakan sarana dan prasana jalan untuk keperluan berlalu lintas merupakan hak yang diberikan untuk setiap orang karena hal tersebut termasuk hak asasi setiap manusia. Dalam hal ini, hak yang sama dimiliki oleh semua orang untuk menggunakan jalan dalam berlalu lintas. Tidak ada 
satupun orang yang mempunyai hak prioritas dalam menggunakan jalan, kecuali didasarkan pada peraturan perundang-undangan yang berlaku.

Di Indonesia, terdapat peraturan perundangundangan yang bertujuan untuk memberikan peluang bagi orang tertentu atau kendaraan yang digunakan bagi keperluan tertentu agar dapat memperoleh prioritas dalam menggunakan jalan untuk berlalu lintas. Hak ini diatur dalam Peraturan Pemerintah (PP) Nomor 43 Tahun 1993. Di dalam Pasal 65 ayat 1 disebutkan bahwa pemakai jalan wajib mendahulukan pemakai jalan lainnya sesuai dengan urutan prioritas berikut:

1. Kendaraan pemadam kebakaran yang sedang melaksanakan tugas

2. Ambulans yang mengangkut orang sakit

3. Kendaraan untuk memberi pertolongan pada kecelakaan lalu lintas

4. Kendaraan Kepala Negara (Presiden dan Wakil Presiden) atau Pemerintah Asing yang menjadi tamu negara

5. Iring-iringan pengantar jenazah

6. Konvoi, pawai atau kendaraan orang cacat

7. Kendaraan yang penggunaannya untuk keperluan khusus atau mengangkut barangbarang khusus.

Berdasarkan ayat 2 Pasal 65 PP No. 43

Tahun 1993, kendaraan yang mendapatkan prioritas tersebut harus disertai dengan pengawalan petugas yang berwenang atau dilengkapi dengan isyarat atau tanda-tanda lain. Kemudian, di dalam ayat 3 ditegaskan lagi bahwa petugas yang berwenang melakukan pengamanan apabila mengetahui adanya pemakai jalan yang diprioritaskan tersebut. Tujuan utama adanya pengawalan tersebut adalah memberikan pengamanan, baik terhadap kendaraan yang dikawal, maupun pengguna jalan lain yang berada di sekitar kendaraan yang dikawal. Apabila terdapat tindakan pengawalan jalan, maka pengguna jalan lain wajib untuk memberikan prioritas kepada kendaraan yang dikawal tersebut.

\section{METODE}

Pengabdian pada masyarakat yang diusulkan pada laporan ini berwujud pelatihan pengenalan rambu-rambu lalu lintas dan prioritas pengguna jalan. Pelatihan ini diberikan kepada anak-anak usia kisaran Taman Kanak-kanak dan Sekolah Dasar yang menjadi anak didik pada Taman Baca Galeri Kreatif. Jumlah peserta didik di Taman Baca tersebut sekitar 100 anak. Pelatihan tersebut dilakukan dengan mengenalkan rambu-rambu lalu lintas pengguna jalan kepada peserta. Setiap tahap dalam pengenalan tersebut akan diberikan pula tambahan media interaktif berupa animasi yang semakin menambah ketertarikan dalam pelatihan yang diikuti.

Mitra pengabdian pada masyarakat ini adalah Taman baca Galeri Kreatif yang awal mulanya didirikan oleh Mas Zaki yang sekarang menjadi pengurus utama Taman Baca tersebut. Berdasarkan hasil komunikasi dengan perwakilan Taman Baca Galeri Kreatif, diketahui bahwa anak didik Taman Baca ini juga memerlukan pendidikan tambahan tentang rambu-rambu lalu lintas dan prioritas utama pengendara jalan raya. Hal tersebut dikarenakan mereka jarang sekali pergi ke kota dan bertemu dengan rambu lalu lintas dan jenis-jenis pengendara jalan raya. Padahal mereka adalah generasi penerus bangsa yang akhirnya juga harus ke kota untuk melanjutkan pendidikan mereka ataupun bekerja. Anak-anak tersebut kelak kalau sudah dewasa juga akan menjadi pelaku lalu lintas.

Pelatihan pengenalan rambu-rambu lalu lintas dan prioritas pengguna jalan menggunakan media interaktif game ini akan dilaksanakan sesuai tahapan berikut:

1. Tahap Pelatihan Pengenalan Rambu-Rambu Lalu Lintas

Tahap pertama game (permainan) mengenai tentang pengenalan rambu-rambu lalu lintas kepada anak-anak. Selain mengenalkan tentang jenis-jenis rambu lalu lintas dan jenis kendaraankendaraan yang sesuai dengan rambu-rambu tersebut. Peserta akan melalui evaluasi pemahaman materi dengan media interaktif yang menyenangkan yaitu berupa animasi sehingga mudah diingat.

2. Tahap Pelatihan Berkendara di jalan

Tahap kedua pengetahuan peserta akan mendapat tantangan untuk berkendara berdasar prioritas pengguna jalan melalui jalan dari start sampai finish. Setelah itu sebagai tolak ukur evaluasi pemahaman peserta dilakukan dengan media interaktif berupa animasi permainan agar materi lebih mudah diingat dan memberikan ilustrasi nyata kepada anak-anak peserta pelatihan.

3. Penyerahan Laptop

Untuk mendukung sarana belajar anak-anak didik di Taman Baca Galeri khususnya sebagai alat untuk mengoperasikan permainan rambu-rambu lalu lintas, maka pihak pelaksana pengabdian pada masyarakat akan menyerahkan satu unit laptop yang diserahkan secara simbolis kepada pengurus galeri.

\section{HASIL DAN PEMBAHASAN}


Pada awalnya rencana pengabdian kepada masyarakat ini direncanakan dengan memberikan pelatihan pengenalan rambu-rambu lalu lintas dan prioritas pengguna jalan menggunakan media interaktif sebagai upaya membangun karakter positif sejak dini kepada para relawan di taman baca galeri kreatif di Wonokerto, Malang. Dengan adanya pelatihan tersebut para peserta dapat memahami rambu-rambu lalu lintas kepada anak-anak dan jenis kendaraan-kendaraan yang sesuai dengan ramburambu tersebut. Peserta juga diharapkan memahami jenis-jenis pengguna yang diprioritaskan beserta alasan urutan prioritas pengguna jalan. Segala persiapan sudah dilakukan baik secara materi dan non materi. Namun pada bulan Maret 2020 pandemi COVID-19 yang "menyerang" masyarakat Indonesia sehingga seluruh aktifitas mulai dibatasi.

Pada akhirnya kegiatan Pengabdian pada masyarakat tidak dapat dilaksanakan seperti rencana awal. Tim mengganti acara pelatihan tersebut dengan memberikan bantuan kepada pihak Taman Baca Galeri Kreatif berupa laptop Acer Aspire A314-33C27F pada tanggal 1 Agustus 2020. Diharapkan dengan adanya laptop tersebut dapat membantu pihak Taman Baca Galeri Kreatif dalam mengembangkan kompetensi para relawan yang ada disana. Selain penyerahan bantuan perangkat TIK, kegiatan ini juga sekaligus memberikan bimbingan teknis tentang cara pemanfaatan perangkat yang diberikan dan penggunaan aplikasi yang dibangun. Dengan demikian, diharapkan para relawan tersebut dapat menerapkan pembelajaran berbasis TIK secara optimal di Taman Baca Galeri Kreatif. Gambar 1 merupakan dokumentasi penyerahan laptop dari tim kepada pihak Taman Baca Galeri Kreatif.

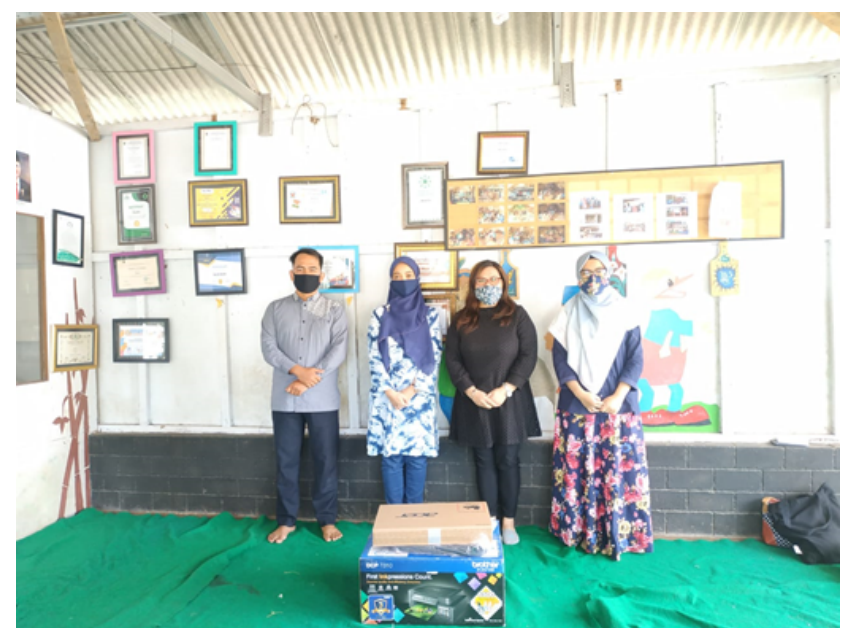

Gambar 1 Penyerahan laptop kepada pihak taman baca galeri kreatif
Selanjutnya, Gambar 2 merupakan salah satu fitur dari permainan yang dibangun. Fitur permainan tebak fungsi merupakan permainan yang menampilkan rambu-rambu dan user diharuskan untuk menebak fungsi dari rambu tersebut dengan waktu yang telah disediakan oleh setiap permainan yang dimainkan.

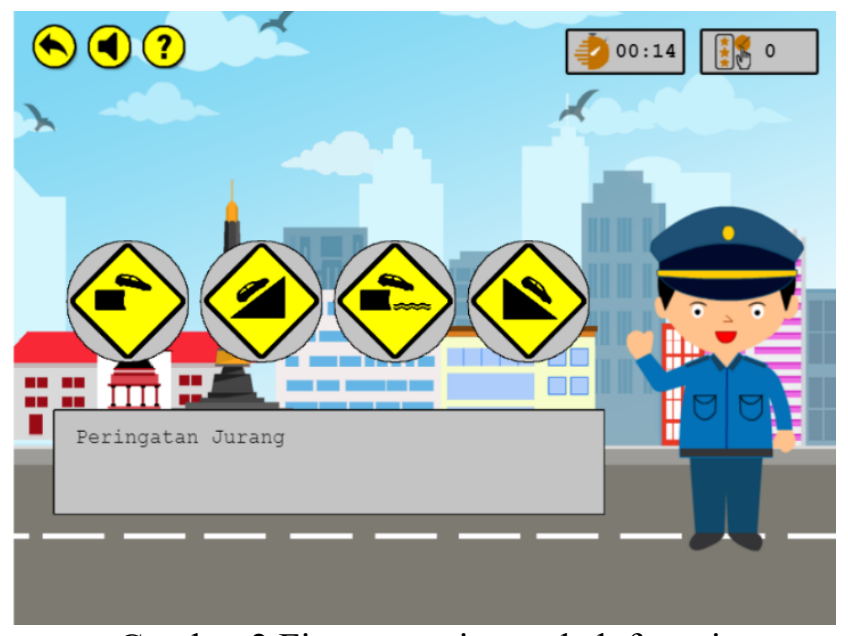

Gambar 2 Fitur permainan tebak fungsi

Gambar 3 merupakan fitur permainan coba berkendara merupakan permainan untuk mencoba berkendara dijalan yang sudah disediakan ramburambu yang harus dipatuhi oleh user, dan pada permainan berkendara ini dapat mengumpulkan koin emas dengan waktu yang telah disediakan.

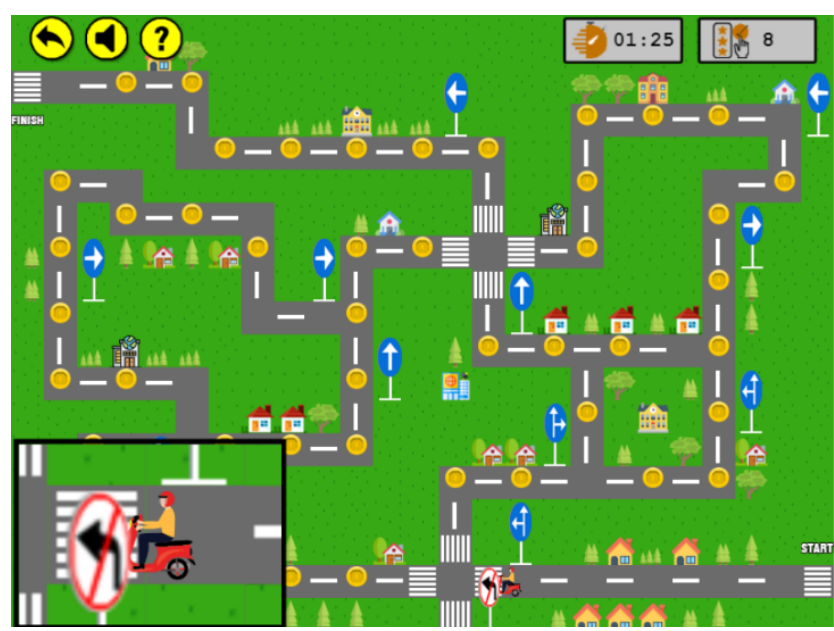

Gambar 3 Fitur permainan coba berkendara

Adanya aplikasi pengenalan rambu-rambu lalu lintas dan prioritas pengguna jalan diharapkan peserta dapat memahami rambu-rambu lalu lintas. Selain itu peserta juga diharapkan memahami jenisjenis pengguna yang diprioritaskan beserta alasan urutan prioritas pengguna jalan. Gambar 4 
merupakan hasil rekapan dari uji coba mengerjakan soal tebak fungsi dalam bentuk pilihan ganda.

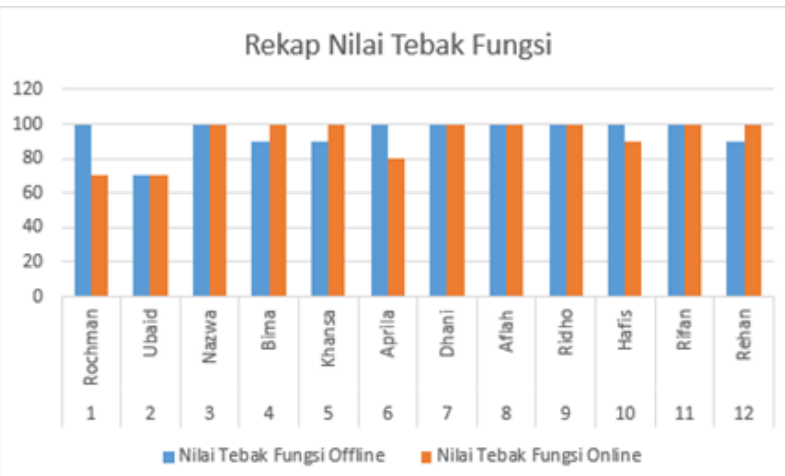

Gambar 4 Rekap nilai tebak fungsi

Gambar 4 adalah perbandingan hasil mengerjakan soal ditampilkan dalam bentuk chart untuk mempermudah perbandingan ketika hasil online dan offline. Dapat dilihat pada chart tersebut bahwa dari 12 peserta yang mengerjakan soal secara online dan offline, terdapat 3 orang peserta mengalami peningkatan, 3 orang peserta mengalami penurunan, dan 6 orang peserta mendapat nilai yang sama dalam mengerjakan soal online. Selain itu juga dilakukan uji coba mengerjakan soal cocokan puzzle atau menyesuaikan fungsi rambu. Gambar 5 merupakan hasil uji coba yang telah dilakukan.

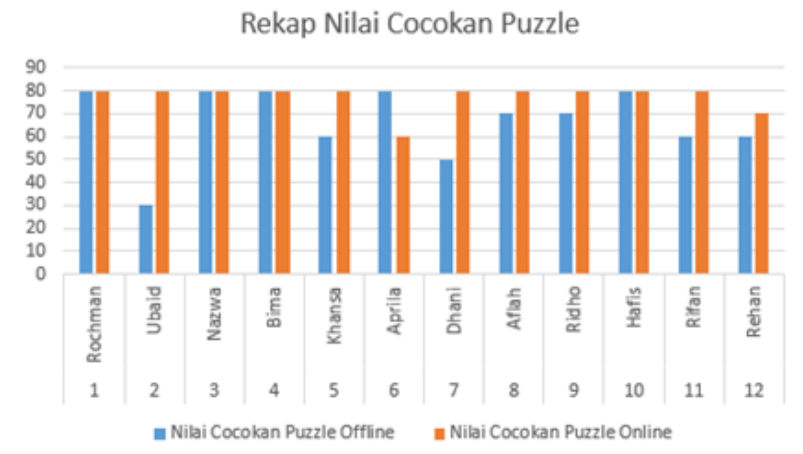

Gambar 5 Rekap nilai cocokkan puzzle

Pada Gambar 5, perbandingan hasil mengerjakan soal ditampilkan dalam bentuk chart untuk mempermudah perbandingan ketika hasil online dan offline. Dapat dilihat pada chart tersebut bahwa dari 12 peserta yang mengerjakan soal secara online dan offline, terdapat 7 orang peserta mengalami peningkatan, 1 orang siswa mengalami penurunan, dan 4 orang peserta mendapat nilai yang sama dalam mengerjakan soal online.

\section{KESIMPULAN}

Kegiatan pelatihan pengenalan rambu-rambu lalu lintas dan prioritas pengguna jalan menggunakan media interaktif sebagai upaya membangun karakter positif sejak dini yang dilaksanakan di Taman Baca Galeri Kreatif di Wonokerto, Malang ini terbagi menjadi 2 sub kegiatan. Kegiatan pertama adalah membangun aplikasi interaktif yang akan digunakan dalam pelatihan nanti. Kegiatan berikutnya adalah kegiatan pelatihan di Taman Baca Galeri Kreatif itu sendiri.

Dari segi pengembangan media interaktif, uji coba mengerjakan soal tebak fungsi dalam bentuk pilihan ganda, terdapat keberhasilan signifikan yang dapat dilihat dari 12 peserta yang mengerjakan soal baik secara online maupun offline, dengan 7 orang peserta yang mengalami peningkatan, 1 orang siswa yang mengalami penurunan, dan 4 orang peserta lainnya mendapatkan nilai yang sama dalam mengerjakan soal online.

Selanjutnya dari segi pelaksanaan pelatihan itu sendiri, dengan adanya keterbatasan pelaksanaan yang dikarenakan Pandemi COVID-19 pada awal Maret 2020, maka program pengabdian ini yang semula berencana mengadakan acara pelatihan pengenalan rambu lalu lintas dengan menggunakan media interaktif digantikan dengan memberikan bantuan berupa laptop Acer Aspire A314-33-C27F kepada pihak Taman Baca Galeri Kreatif pada tanggal 1 Agustus 2020.

Selain penyerahan bantuan berupa perangkat TIK tersebut diatas, kegiatan pengabdian ini juga sekaligus memberikan bimbingan teknis berupa cara pemanfaatan perangkat TIK yang diberikan dan penggunaan aplikasi yang telah dibangun. Tujuan pemberian perangkat TIK ini adalah agar perangkat tersebut dapat membantu pihak Taman Baca Galeri Kreatif mengembangkan kompetensi TIK para relawan yang ada disana sehingga pada akhirnya nanti para relawan tersebut dapat menerapkan pembelajaran berbasis TIK secara optimal di taman baca.

\section{SARAN}

Saran dari kegiatan pengabdian pada masyarakat ini antara lain sebagai berikut:

- Para relawan perlu diberikan wawasan lebih dalam lagi dibidang IT agar bisa mengaplikasikan langsung dan berbagi pengetahuan tersebut dengan masyarakat sekitar.

- Para relawan perlu diberikan motivasi untuk lebih memahami dunia IT. 
Pengembangan aplikasi yang baik adalah pengembangan aplikasi dengan sisi manfaat dan sisi kerja sistem yang baik. Sehubungan dengan hal tersebut, berikut ini adalah saran untuk pengembangan aplikasi ini lebih lanjut:

- Sistem pada aplikasi ini bisa dikembangkan dengan versi Android.

- Penambahan referensi rambu-rambu lalu lintas agar lebih lengkap.

- Manajemen akun pada aplikasi ini dapat lebih disempurnakan.

Diharapkan pengembang berikutnya dapat menambah nilai dari aplikasi tersebut pada nantinya.

\section{UCAPAN TERIMA KASIH}

Penulis mengucapkan terima kasih kepada Politeknik Negeri Malang melalui UPT P2M Polinema sehingga proses pelaksanaan program pengabdian kepada masyarakat dapat terlaksana dengan baik.

\section{DAFTAR PUSTAKA}

[1] Irhandayaningsih, A., 2019, Menanamkan Budaya Membaca pada Anak Usia Dini, Anuva, No. 2, Vol. 3, pp. 109-118.

[2] Surtiawati, C., 2009, Menumbuhkan Minat Membaca Sebagai Upaya Peningkatan Mutu Tenaga Pendidik Paud Di Indonesia, J. Ilm. Visi, No. 2, Vol. 4, pp. 204-20.

[3] Salsabilah, I. D., Hakim, Z. R., Taufik, M., 2020, Proses Penanaman Karakter Gemar Membaca Pada Siswa Kelas III Melalui Pelaksaaan Program Literasi di SDN Banjar Sari 5, J. Ilm. Pendidik. Guru Sekol. Dasar, No.2, Vol. 4, pp. 115-126.

[4] Haryanti, A., Dindin, 2020, Meningkatkan Minat Baca Pada Anak Usia Dini, J. Loyal. Sos. J. Community Serv. Humanit. Soc. Sci., No.2, Vol. 2, pp. 103-114.

[5] Rahmawati, Z.D., 2020, Penggunaan Media Gadget dalam Aktivitas Belajar dan Pengaruhnya Terhadap Perilaku Anak, TA"LIM J. Stud. Pendidik. Islam, No. 1, Vol. 3, pp. 97-113.

[6] Hijriyani, Y.S., Astuti, R., 2020, Penggunaan Gadget pada Anak Usia Dini dalam Menghadapi Era Revolusi Industri 4.0, ThufuLA J. Inov. Pendidik. Guru Raudhatul
Athfal, No. 1, Vol. 8, pp. 15-28.

[7] Hartati, S., 2019, Pengaruh Media Audio Visual Terhadap Stimulasi Sensori PenDengaran Bagi Anak Toddler di TPA/PAUD, Early Child. Educ. J., No. 1, Vol. 2, pp. 1-5.

[8] Heinich, R., Molenda, M., Russell, J., 2002, Instructional Media and Technology for Learning, Prenctice Hall, New Jersey.

[9] Azhar, A., 2002, Media Pembelajaran, Raja Grafindo Persada, Jakarta.

[10] Martono, K. T., 2016, Rancang Bangun Media Pengenalan Rambu-rambu Lalulintas Dengan Memanfaatkan Teknologi Augmented Reality, J. Teknol. informasi-Aiti, No.1,Vol. 14, pp. 49-58.

[11] Sugiman, V. R., Cahyana, R., Bunyamin, 2014, Pengembangan Aplikasi Rambu Lalu Lintas Berbasis Android Menggunakan Metode Prototyping, J. Algoritm., No. 1, Vol. 11, pp. 164-173. 